\title{
Impact Assessment of Frontline Demonstration on Integrated Nutrient Management in Tomato Crop in Rajkot District of Gujarat, India
}

\author{
A. R. Parmar*, S. V. Undhad, V. S. Prajapati and N. B. Jadav
}

Krishi Vigyan Kendra, Junagadh Agricultural University, Pipalia (Rajkot), Gujarat, India

*Corresponding author

\section{A B S T R A C T}

\section{Keywords \\ Tomato, Frontline demonstration, Yield, Economics, Technology gap, Extension gap, Technology index, INM}

\section{Article Info}

Accepted:

21 May 2020

Available Online:

10 June 2020
The study was conducted in a farmer's field of Rajkot district, Gujarat, to assess the impact of integrated nutrient management (INM) of tomato crop during Kharif (2017 to 2019) with 30 numbers of farmers. Front line Demonstration was conducted by foliar spraying of multi-micronutrient formulation Grade IV (Fe-Mn-Zn-Cu-B, 4.0-1.0-6.0-0.5-0.5 \%) @ 1\% at 45, 60 and 75 DAS in addition to a recommended dose of fertilizers (75-37.5-62.5 N$\mathrm{P} 2 \mathrm{O} 5-\mathrm{K} 2 \mathrm{O} \mathrm{kg} / \mathrm{ha}$ ) to tomato for getting higher yield and net return. The demonstrated technologies were performed better in all years compare to farmer's practices. In the demonstrated plot, the average yield of three years was recorded $275.86 \mathrm{q} / \mathrm{ha}$ as compared to local practices $247.83 \mathrm{q} / \mathrm{ha}$. The average percent increase in yield of the demonstrated plot was recorded $9.75 \%$ during the three years of programs. The technology gap, the Extension gap, and technology index values were $40.7 \mathrm{q} / \mathrm{ha}, 28.03 \mathrm{q} / \mathrm{ha}$, and $12.85 \%$, respectively. The research practices gave higher average gross return (Rs. 206531/ha), net return (Rs. 145837/ha) with a higher B: C ratio (1:3.36) as compared to the framer's practices. By conduction front line demonstrations on farmer's field, there was a significant increase in the knowledge level of the farmer's and the majority of farmers showed a high level of satisfaction about INM Technology in tomato.

\section{Introduction}

Tomato (Lycopersicon escullentum, Mill) is an important vegetable crop grown almost throughout the world including tropical and temperate regions. It is cultivated both in the greenhouses on protective structures as well as under natural conditions. It ranks first among processed vegetables. It is consumed fresh in salad, a friend in culinary preparations, and processed in various forms viz. ketchup, sauces, puree, paste, powder, juice soup, and chutney, etc. Tomato is a rich source of Vitamins $\mathrm{A}$ and $\mathrm{C}$ and is referred to as "poor man's Orange". It adds a variety of colors to the food. Tomato is a very good appetizer and its soup is said to be a good remedy for patients suffering from constipation. Lycopene that imparts red color to ripe tomatoes is reported to possess anticancerous properties. It also serves as a natural anti-oxidant as the Beta-carotene functions to help prevent neutralize free radical chain reaction and ascorbic acid is an 
effective scavenger of superoxide, hydrogen peroxide, single oxygen and other free radicals (Dhaliwal, 2014). In India tomato is grown throughout the country. The leading tomato growing states are Karnataka, Andhra Pradesh, Orissa, Bihar, Gujarat, and West Bengal. In Gujarat, it grows in 47575 ha area with the production of 136 lakh tone (Anonymous, 2018). The requirement of micronutrients like $\mathrm{Zn}, \mathrm{Cu}, \mathrm{Mn}, \mathrm{Fe}, \mathrm{B}$, and Mo are relatively less but their role in normal crop production is indispensable because of their active role in plant metabolic processes involving cell wall development, respiration, photosynthesis, chlorophyll formation, enzyme activity, and nitrogen fixation. The majority of tomato growers do not produce good quality fruit at high yield due to lack of knowledge regarding improved production technologies including the use of proper inorganic and organic fertilizers. The Indian Council of Agricultural Research has implemented a new fully-funded program in the mid-eighties i.e. Front Line Demonstrations for transfer of technology to farmers. The main objective of front line demonstrations is to demonstrate newly released crop production technologies and its management practices in the farmer's field under farming situations and at different agroclimatic regions (Meena, 2011 and Narasimha Rao et al., 2007). The field demonstrations conducted under the close supervision of scientists of the National Agriculture Research System is called front- line demonstrations because the technologies are demonstrated and critically examined by the scientists themselves before being fed into the main extension system of the State Department of agriculture. While demonstrating the technologies in the farmer's field, the scientists are required to study the factors contributing to higher crop production, production constraints and thereby, generate production data and feedback information. Under this unique program, Krishi Vigyan Kendra, JAU, Pipalia, has conducted the front line demonstrations (FLD's) on INM in Tomato in Thirty demonstration from 2017-18 to 201920 in the jurisdiction of Krishi Vigyan Kendra. The present study has been undertaken to evaluate the difference between demonstrated technologies followed by the farmer's practices in Tomato crop.

\section{Materials and Methods}

The present study was carried out by the Krishi Vigyan Kendra, JAU, Pipalia (Rajkot) in Kharif season in the ten farmer's field of Rajkot district during 2017-18 to 2019-20. All 30 front line demonstrations in 12 ha areas were conducted in different villages with the active participation of farmers. Before conducting FLDs a list of farmers was prepared from group meetings and specific skill training was imparted to the selected farmers regarding a different aspect of cultivation (Venkattakumar et al., 2010). The objective of FLD's was to transfer the improved varietal technology to increase the productivity of Tomato. The difference between a demonstration package and existing farmer's practice is given in Table 1. All demonstrations were conducted on medium black soils with an area of 0.4 ha. Front line Demonstration was conducted by foliar spraying of multi-micronutrient formulation Grade IV (Fe-Mn-Zn-Cu-B, 4.01.0-6.0-0.5-0.5\%) @ 1\% at 45, 60 and 75 DAS in addition to a recommended dose of fertilizers (75-37.5-62.5 N-P2O5-K2O kg/ha) to tomato for getting higher yield and net return. The necessary steps follow for the selection of site and farmers, the layout of the demonstration. The data output was collected from both demonstrated plot as well as farmers practices and finally, the extension gap, technology gap, technology index along with benefit-cost ratio were workout (Samui et al., 2000) as given below: 
Technology gap $=$ Pi $($ Potential yield $)-\mathrm{Di}$ (Demonstration yield)

Extension gap $=$ Di $($ Demonstration yield $)-$ Fi (Farmers Yield)

Technology index $(\%)=($ Technology gap $/$ Potential yield) $\times 100$

\section{Results and Discussion}

\section{Yield}

The data presented in Table 2 it's revealed that INM technology in tomato performed better in all three years as compared to farmer practices. The INM technology in tomato recorded maximum and minimum yield in Kharif season year 2018-19 and 2017-18 with $281.0 \mathrm{q} / \mathrm{ha}$ and $271.6 \mathrm{q} / \mathrm{ha}$, respectively. The average yield of three years was recorded $275.0 \mathrm{q} /$ ha as compared to local variety 247.3 $\mathrm{q} / \mathrm{ha}$. The percent increase in yield was ranging from 9.31 to 10.20 with an average of $9.75 \%$ during the three-year FLD programs. Similar yield enhancement in different crops in frontline demonstration has been documented by Poonia and Pithia (2011), Patel et al., (2013) and Raj et al., (2013). It is evident from the results that the yield of INM technology was found better than the local farmer's practices under the same environmental conditions. Farmers were motivated by the results of demonstrated agro-technologies applied in the FLDs and it is anticipated that they would adopt these technologies in the future. The yield of front line demonstration and potential yield of the crop as compared to estimate the yield gaps which were further categorized into technology index.

\section{Technology gap}

The technology gap is the demonstration yield over potential yield. The technology gap was ranged between 35.5-44.9 q/ha with a mean of three years $40.63 \mathrm{q} / \mathrm{ha}$ during the period of study. The technology gap may be attributed to the dissimilarity in the soil fertility status and weather conditions (Mukherjee, 2003 and Mitra and Samajdar, 2010).

\section{Extension gap}

The highest extension gap was $35 \mathrm{q} / \mathrm{ha}$ recorded in the year 2019-20 and a minimum of $23.1 \mathrm{q} / \mathrm{ha}$ was observed in the year of 2017-18. This emphasized the need to educate the farmers through various means for the adoption of improved agricultural production technologies to reverse this trend of wide extension gap. More and more use of the latest production technologies with high yielding variety will subsequently change this alarming trend of the galloping extension gap. The new technologies will eventually lead to the farmers to discontinue the old technology and to adopt new technology. This finding is in corroboration with the findings of Hiremath and Nagaraju (2010).

\section{Technology index}

The technology index shows the feasibility of the technology in the farmer's field. The lower the value of the technology index more is the feasibility. As such, fluctuation in the technology index was presented in Table 1 that is from 11.21 to 14.18 percent during the period of study. These findings corroborate with the findings of Mokidue et al., (2011) and Tomar (2003).

\section{Economics of frontline demonstrations}

The year-wise economics of tomato cultivation with the adoption of improved technology and farmer's practices has been presented in Table 2. 
Table.1 Productivity, technology gap, extension gap and technology index of chickpea under FLDs

\begin{tabular}{|c|c|c|c|c|c|c|c|c|c|}
\hline \multirow{2}{*}{$\begin{array}{l}\text { Sr. } \\
\text { No }\end{array}$} & \multirow[t]{2}{*}{ Year } & \multirow{2}{*}{$\begin{array}{c}\text { No. of } \\
\text { Farmers }\end{array}$} & \multirow{2}{*}{$\begin{array}{l}\text { Area } \\
\text { (ha) }\end{array}$} & \multicolumn{2}{|c|}{ Yield (Kg/ha) } & \multirow{2}{*}{$\begin{array}{c}\% \\
\text { Increase } \\
\text { over } \\
\text { control }\end{array}$} & \multirow{2}{*}{$\begin{array}{c}\text { Technology } \\
\text { Gap (Kg/ha) }\end{array}$} & \multirow{2}{*}{$\begin{array}{c}\text { Extension } \\
\text { gap } \\
\text { (Kg/ha) }\end{array}$} & \multirow{2}{*}{$\begin{array}{l}\text { Technology } \\
\text { Index }(\%)\end{array}$} \\
\hline & & & & $\begin{array}{c}\text { Demonstrated } \\
\text { practices }\end{array}$ & $\begin{array}{l}\text { Farmer's } \\
\text { practices }\end{array}$ & & & & \\
\hline 1 & 2017-18 & 10 & 4 & 271.6 & 248.5 & 9.31 & 44.9 & 23.1 & 14.18 \\
\hline 2 & $2018-19$ & 10 & 4 & 281.0 & 255.0 & 10.20 & 35.5 & 26 & 11.21 \\
\hline \multirow[t]{2}{*}{3} & $2019-20$ & 10 & 4 & 275.0 & 240.0 & 9.75 & 41.5 & 35 & 13.11 \\
\hline & Average & 10 & 4 & 275.86 & 247.83 & 9.75 & 40.63 & 28.03 & 12.83 \\
\hline
\end{tabular}

Table.2 Economics of frontline demonstrations

\begin{tabular}{|c|c|c|c|c|c|c|c|c|}
\hline \multirow{2}{*}{ Year } & \multicolumn{2}{|c|}{$\begin{array}{c}\text { Cost of Cultivation } \\
\text { (Rs./ha) }\end{array}$} & \multicolumn{2}{c|}{ Gross return (Rs./ha) } & \multicolumn{2}{c|}{ Net return (Rs./ha) } & \multicolumn{2}{c|}{ B:C ratio } \\
\cline { 2 - 10 } & DP & FP & DP & FP & DP & FP & DP & FP \\
\hline $\mathbf{2 0 1 7 - 1 8}$ & 60500 & 65000 & 203718 & 186375 & 143218 & 121375 & 3.37 & 2.87 \\
\hline $\mathbf{2 0 1 8 - 1 9}$ & 61081 & 65000 & 210750 & 191250 & 149669 & 126250 & 3.35 & 2.94 \\
\hline $\mathbf{2 0 1 9 - 2 0}$ & 60500 & 65000 & 205125 & 182350 & 144625 & 117350 & 3.36 \\
\hline Average & 60693 & 65000 & 206531 & 186658 & 145837 & 121658 & 3.36 \\
\hline
\end{tabular}

$\mathrm{DP}=$ Demonstrated practices, $\mathrm{FP}=$ Farmer practices 
The results of economic analysis of tomato production revealed that the average gross expenditure of demonstration practices was $3.13 \%$ higher than farmer's practices But, front line demonstrations average of three years recorded higher gross returns (Rs. 210750/ha) and net return (Rs. 149669/ha). The benefit-cost ratio of demonstration practices (1:3.36) also more than the farmer's practice. Sreelakshmi et al., (2012), Joshi et al., (2014) and Sharma et al., (2016) also reported higher net returns and $\mathrm{B}: \mathrm{C}$ ratio in the FLDs on improved technologies compared to the farmer's practices and are at par with results in higher net returns through FLDs on improved technologies.

In conclusion, the findings of the study revealed that a wide gap exists in demonstration yield and farmer's practices in tomato due to technology and extension gap in the Rajkot district of Gujarat. The percent increment in yield of tomato to the extent of 9.75\% in FLDs over the farmers' practices created greater awareness and motivated the other farmers to adopt the improved package of practices of INM. These demonstrations trail also enhance the relationship and confidence between farmers and KVK scientists. The recipient farmers of FLDs also play an important role as a source for wider dissemination of the INM technology other nearby farmers. It is concluded that the FLD program is a successful tool in enhancing the production and productivity of Vegetable crops through changing the knowledge, attitude, and skill of farmers.

\section{References}

Anonymous., 2018. Directorate of Horticulture, Gujarat State, Gandhinagar.

Dhaliwal M.S., 2014 Handbook of Vegetable crops, Kalyani Publishers Pp, 38-39

Hiremath, S. M. and Nagaraju, M. V. 2010.
Evaluation of on-farm front line demonstrations on the yield of chilli. Karna. J. Agril. Sci., 23(2):341-342.

Joshi, N. S. Bariya, M. K. and Kunjadia, B. B. 2014. Yield gap analysis through front line demonstrations in wheat crop. International Journal of Scientific Research Publication, 4(9):1-3.

Meena, K. C. 2011. An impact assessment of frontline demonstrations (flds) on soybean growers. Raj. J. Ext. Edu., 19:133-138.

Mitra, B. and Samajdar, T. 2010. Field gap analysis of rapeseed-mustard through front line demonstration. Agricultural Extension Review, 22: 16-17.

Mokidue, I. Mohanty, A. K. and Sanjay, K. 2011. Corelating growth, yield and adoption of urdbean technologies, Ind. J. Ext. Edu., 11(2):20-24.

Mukherjee N. 2003. Participatory, learning and action. Concept, Publishing Company, New Delhi, Pp. 63-65.

Narasimha, Rao, S., Satish, P. and Samuel, G. 2007. Productivity improvement in soybean (Glycine $\max$ L. Merrill) through technological interventions. $J$. Oilseeds Res., 24(2): 271-273.

Patel, M. M., Jhajharia, A. K., Khadda, B. S. and Patil, L. M. (2013). Front-line Demonstration: An effective Communication Approach For dissemination of sustainable cotton production technology. Indian Journal of Extension Education and Rural Development, 21: 60-62.

Poonia, T. C. and Pithia M.S. 2011. Impact of front line demonstrations of chickpea in Gujrat. Legume Research, 34(4):304307.

Raj, A. D., Yadav, V. and Rathod, J. H. (2013). Impact of Front Line Demonstrations (FLD) on the yield of pulses. International Journal of Scientific and Research Publications. Volume 3, Issue 9, September 2013. 
Samui, S. K., Maitra, S., Roy, D. K., Mandal, A.K. and Saha, D. 2000. Evaluation of front line demonstration on groundnut (Arachis hypogeal L.) Journal of Indian Society of Coastal Agricultural Research, 18(2):180-183.

Sharma, Vivek, Kumar, V. Sharma, S. C. and Singh, S. 2016. Productivity enhancement and popularization of improved production technologies in wheat through frontline demonstrations. Journal of Applied Natural Science, 8(1):423-428.

Sreelakshmi, C. H., Sameer Kumar, C. V. and Shivani, D. 2012. Productivity enhancement of pigeonpea (Cajanus cajan L.) through improved production technology. Madras Agricultural Journal, 99(4-6): 248-250.

Tomar, L. S., Sharma, B. P. and Joshi, A. 2003. Impact of frontline demonstration of soybean in transfer of improved technology. J. Ext. Edu., 22(1):139.

Venkattakumar, R., Ramana Rao, S. V. Padmaiah, M. and Madhuri, P. 2010. Production constraints and information needs of oilseeds growers in Andhra Pradesh. Agricultural Extension Review, 22(2): 25-28.

\section{How to cite this article:}

Parmar, A. R., S. V. Undhad, V. S. Prajapati and Jadav, N. B. 2020. Impact Assessment of Frontline Demonstration on Integrated Nutrient Management in Tomato Crop in Rajkot District of Gujarat, India. Int.J.Curr.Microbiol.App.Sci. 9(06): 3260-3265.

doi: https://doi.org/10.20546/ijcmas.2020.906.389 